\title{
ECONOMIC RISKS FACING AFGHANISTAN: FAILED STATES AND BUREAUCRATIC RESISTANCE
}

\author{
J. RYAN TESTON, MEGAN E. KONYNDYK, \\ ROBERT C. FERGUSON \& AUDREY HEFFRON-CASSERLEIGH \\ Florida State University, USA
}

\begin{abstract}
The future of Afghan geopolitics is difficult to predict. Given the current state of infrastructure as well as pending currency collapse, and considering rapid inflation in the country, Afghanistan faces the risk of becoming a failed state if it is unable to secure stable relationships with bordering countries such as Pakistan, China, and Russia. The Taliban now have control of natural resources in the country that were last valued at $\$ 3$ trillion. Some of these resources are in extremely high demand globally and could point to a large profit source for Afghanistan, or a conflict hotbed, should the Taliban be unable to maintain stability and security. Pakistani officials are speculating Afghanistan could join the ChinaPakistan Economic Corridor (CPEC) and senior Taliban officials have expressed a desire for positive relations with China, as well as openness to China's interest in potential investment in mining in Afghanistan. Lack of recognition by the United States for the Taliban as the official leader of Afghanistan, as well as US and United Nations Security Council Sanctions on Afghanistan have had major impacts on investment and flow of aid to the country. The threat of terrorist organizations within Afghanistan will impact its geopolitical relations and ability to develop economic partnerships.

Keywords: Afghanistan, China, Pakistan, economy, risk, Taliban, terrorism, opium, mining.
\end{abstract}

\section{INTRODUCTION}

Failed states are unable to act as a service provider while, "strong states unquestionably control their territories and deliver a full range and a high quality of political goods to their citizens" (Rotberg [1]). Failed or "fragile" state indices easily apply to Afghanistan, but the implication of this label is more nuanced in a region fraught with failed states. Afghanistan, a failed state with a long history of armed conflict, may cause shock to neighboring countries that enjoy "strong state" attributes, generally defined as a state capable of providing political goods to its citizens. Research indicates that failed states influence their region's stability and "states which are generated by political instability and armed conflict, in turn generate subsequent unrest, instability, interstate, and civil war in their neighbors and near regions" (Iqbal and Starr [2]). This diffusion of failure can be compounded by the presence of violent conflicts. As resources diminish, the possibility of civil unrest or interstate conflict increases. Markers of unrest can be difficult to discern in a weak state and are impossible to measure in a failed state.

Through utilizing the state failure as an independent variable, Iqbal and Starr examine unrest, instability, civil war, state failure, and international war as measured dependent variables. Ultimately, it is determined that state failure is unlikely to spread to neighboring countries but there are still increased risks of unrest, instability, and civil war to states with close proximity, and more so to those that share borders with the failed state where research suggest "state failure in a contiguous state increases the odds of civil war by $45 \%$ and the odds of international conflict by $115 \% \ldots$... [presenting] an especially attractive target for invasion, thus providing opportunities and incentives for interstate armed conflict" (Iqbal and Starr [2]).

Bureaucratic resistance is present when there is a conflict between elected or appointed leaders and the civil servants who work within the organization. Extensive research on 
bureaucratic resistance and the national security state suggest that bureaucratic resistance can extend into the national security arena and effect the military and the security of the nation (Ingber [3]). Combined with Afghanistan's failed state status, the presence of bureaucratic resistance also contributes to the instability of its future.

While interstate conflict between Afghanistan and her neighbors seems unlikely, timely interventions could be a factor in disrupting the diffusion of state failure. Neighbors, such as China, which exhibit strong state attributes, may be more resistant to the effects of a failed state neighbor. Neighbors with weak state attributes, including political unrest or the inability to interact as a full member of the international community, may have increased impacts (Iqbal and Starr [2]).

\section{CURRENT ECONOMIC CONDITION}

If the Taliban can effectively maintain control in the face of the looming civil crisis, they face tremendous roadblocks towards successfully legitimizing their governance and advancing Afghanistan away from the world's lowest life expectancy at 53.25. Afghanistan also faces unique challenges including being one of the world's poorest populations with an average Gross Domestic Product (GDP) per capita of $\$ 2,065.00$, terrorist organizations opposed to Taliban ideology, and the emergence of the National Resistance Front of Afghanistan (CIA [4]). The withdrawal of U.S. forces from Afghanistan, while controversial, coupled with the lightning-fast Taliban takeover, predictable yet unplanned for, raises more questions and concerns regarding the troubled state than it initially solved. While it is impossible to predict, numerous economic avenues, partnerships, and global statuses can be explored to examine what may lie ahead.

Entering the last quarter of 2021, the economy of Afghanistan is struggling with slow economic growth caused by deteriorating security conditions, intense drought negatively impacting agriculture, and a third wave of COVID-19 that began in April. Underserviced and isolated, the Afghanis enter winter with record high infection rates in a population with less than 5\% fully vaccinated (World Bank [5]). This trend is inevitable given the gradual increase in inflation in the first 6 months of 2021, followed by an additional acceleration of inflation as the Afghani depreciated against the US dollar by approximately $4 \%$ after the Taliban took control in August (World Bank [5]). The World Bank notes that the Taliban is only getting about $50-60 \%$ of the daily average customs collections (based on 2020 data). The banking system in Afghanistan is in crisis. Despite banks reopening, firms and individuals are hitting withdrawal limits and not able to access higher amounts. This has resulted in limited ability to conduct business, since firms are unable to send funds overseas, as well as long lines of people waiting to withdraw funds. These are crushing variables and it's not possible to accurately assess changes to the exchange rate due to fragmentation of the financial market (World Bank [5]). This leaves Afghanistan in a dire economic and development situation.

The decrease in international aid and grants has worsened an already grim situation. Foreign aid made up 43\% of Afghanistan's economy in 2020 (World Bank [5]). The US has blocked Afghanistan's access to 9.4 billion dollars in international reserves and the International Monetary Fund has paused release of 400 million dollars to Afghanistan (Rappeport [6]). Citing a variety of factors, the World Bank ceased distribution of aid on 24 August (Boghani [7]). The European Union, Germany, and Finland also halted funding for development on August 17, 2021. The World Food Program has stated that 1 in 3 people over 12 million - in Afghanistan are going hungry, and they need 200 million USD to sustain operation to the year's end (WFP [8]). The stoppage of foreign aid is posing huge risks to not only the Afghanistan economy and development, but its people. Despite pledges of humanitarian aid from the US, EU, China, and others, Rina Amira, director of the 
Afghanistan and Regional Policy Initiative at The Center on International Cooperation at NYU, stated "Humanitarian aid will not be sufficient to prevent the collapse of the Afghan economy" (Boghani [7]). For reference, UN member states have pledged more than 1.2 billion in humanitarian aid, but this is contingent on the Taliban abiding by certain behavior (Putz [9]). Compared to the 4.15 billion in Official Development Aid Afghanistan received in 2019 , even if this pledged aid is fully dispersed, it will fall drastically short of what is needed. Return of development aid is also contingent on international recognition of the Taliban-run Afghan government. This is itself contingent upon, among other things, the Taliban upholding promises regarding the rights of women (Boghani [7]). These contingencies regarding aid present further obstacles to an economy teetering on the brink of collapse. Ultimately, the cost will be measured in human lives.

\section{GEOPOLITICAL RELATIONSHIPS}

How the Taliban will finance their government will be heavily influenced by relationships with China, Pakistan, and Russia. The takeover of the country by the Taliban has been supported by Pakistani Prime Minister Imran Khan (Pakistani Country Risk Report [10]). Pakistani senator Mushahid Hussain Sayed said "The best way forward and the immediately available alternative option for Afghanistan's economic development is CPEC, which includes Pakistan and China" (Greenfield [11]). The China-Pakistan Economic Corridor is part of China's Belt and Road Initiative, which has promised more than $\$ 60$ billion to Pakistan for infrastructure projects. Listed among CPECs various projects are the planned power stations in the north of Pakistan, where several stations have been shuttered (CPEC [12]). There is low probability the Taliban could partake in the agreements CPEC required of Pakistan including, but not limited to, the TPPA. The Taliban, as of 8 September 2021, has officially "expressed the group's interest in joining the China-Pakistan Economic Corridor" (CPEC [12]). There would be substantial benefits were this to occur, such as "increased trade of goods, including oil via pipelines among China, Pakistan and Afghanistan" (Pakistan Country Risk Report [10]).

However, there are risks to Pakistan and China involving the Taliban's ability to prevent Afghanistan from becoming a haven to extremists. The very threats posed by a potential surge in extremists in Afghanistan could very well encourage Chinese and Pakistani involvement in an effort to control the situation. In a meeting on 25 October 2021 between Chinese Foreign Minister Wang Yi and acting deputy prime minister of Afghanistan Mullah Abdul Ghani Baradar, Wang conveyed that "the East Turkestan Islamic Movement (ETIM), an international terrorist organization listed by the UN Security Council, not only poses a real threat to China's national security and territorial integrity but also jeopardizes domestic stability and long-term stability in Afghanistan" (The People's Republic of China [13]). In response, Baradar stated "The Afghan Taliban, which attaches great importance to China's security concerns, will resolutely honor its promise and never allow anyone or any force to use the Afghan territory to harm China" (The People's Republic of China [13]). Afghanistan's official message continues following a path which would encourage Chinese support. Chinese officials also urged G20 members to lift economic sanctions on Afghanistan (The People's Republic of China [14]) and officials from China, Russian, Pakistan, and Iran have been in communication regarding Afghanistan (The People's Republic of China [15]). Chinese Foreign Minister Yi presented a "five-point proposal" on Afghanistan, including a proposal to, "help Afghanistan join in regional cooperation" (The People's Republic of China [15]). China has also promised $\$ 31$ million in aid in the form of food and health supplies, including 3 million COVID-19 vaccines (Al Jazeera [16]). Given the population of nearly 39 million (World Bank [17]), this is enough for approximately $3.8 \%$ of the population to get 
fully vaccinated. For Afghanistan, it is clear that any path to avoiding failed state status must involve significant support from its neighbors.

\section{UNTAPPED RESOURCES, CASH CROP ALTERNATIVES \\ AND ILLICIT REVENUE}

Prior to Taliban control, the governmental operations of Afghanistan predominantly relied upon international assistance to maintain effectiveness. At the same time, the Taliban insurgency from 2001 until August 2021, financed their operations through criminal activities both within Afghanistan and internationally (Azami [18]). While kidnappings, taxation of drug cultivation, and exploiting the natural resources of vulnerable communities may be efficient at financing an insurgency, to continue these practices will further isolate the newly reinstituted Taliban government. Currently the Taliban have control of natural resources in the country that were last valued at $\$ 3$ trillion (Daly and Singh [19]). Some of these resources are in extremely high demand globally, and could point to a large profit source for Afghanistan, or a conflict hotbed, should the Taliban be unable to maintain stability and security. Roadblocks in building a stable mining economy include a history of corruption, the poor infrastructure of Afghanistan, issues of occupational safety, and questionable security of mining facilities. Copper, rare-earth metals, and gemstones are mentioned as the most sought-after resources abundant within Afghani borders, but also present are valuable commodities such as marble, natural gas, lithium, zinc, and many more (Daly and Singh [19]). Prior to the collapse of the previous Afghan government, it was reported that officials had control of 281 of the 709 identified mining zones. Of the remaining mines, 280 were under direct Taliban control, with 148 reportedly under the control of local warlords. In all, revenue from illegal mining operations were estimated in 2020 to finance the insurgency at approximately $\$ 464$ million (UNODC [20]). In the history of Afghanistan, large scale investment in mining has failed, and warlords have profited from illegal mining royalties. Previous governments inability to ensure safe working practices by monitoring hours worked, proper training, and child labor, will also be a challenge to the Taliban (Pikulicka-Wilczewska [21]). While much has changed since 2016, estimates upwards of 10,000 deposits were believed to be outside of the previous government's control, and at the time of the reporting, were becoming an increasing avenue for Taliban financing (Kakar [22]).

Security is always the greatest risk in Afghanistan and there is low optimism the Taliban will be able to turn mining operations into a prosperous Afghan economy. The internal risk of attack at the hands of Islamic State-Khorasan (IS-K) continues to be a primary security threat, and potential investors remain cautious of the threat towards infrastructural developments and workers. In addition to the tremendously successful IS-K attack during evacuation operations, the terrorist organization has carried out 47 attacks aimed primarily at Taliban fighters (George et al. [23]).

Along with this vast collection of untapped natural resources, and potential cash crop alternatives, Afghanistan has largely controlled the opium market for decades, and while illicit, it has been a primary source of funding for the Taliban since their removal at the hands of U.S. and NATO forces in 2001 (UNODC [20]). Should the Taliban choose to once again adopt policies against opium cultivation, without exploring alternative crops that can ensure the financial security of rural communities as they did during their previous reign, this could prove disastrous for rural Afghanis who will be faced with the upheaval of their livelihood. Previously, at the hands of historically violent rule of law by the Taliban government, farmers had to choose to either adhere to the changing landscape or violate enacted policies. 
As of September 2021, annual income for the Taliban reportedly ranged from $\$ 300$ to $\$ 1.6$ billion, with a large portion of annual revenue coming from opium poppy cultivation, and additional supplemental financial needs met through mining and donations (Maizland [24]). Should the Taliban re-establish bans upon opium poppy cultivation, it will further escalate the economic disparity of rural Afghanis who rely upon the crop for their income, and the Taliban who have relied upon generating tax income from its cultivation. By examining the most recent Afghanistan Opium Survey, conducted by the UN Office of Drugs and Crime, the 2020 opium production in the country is estimated at 224,000 hectares, with only 12 of Afghanistan's 36 Provinces not involved in substantial agricultural growth of the crop. Total USD value of the farm-gate price in 2020 totals $\$ 350$ million, and while this pales in comparison to the pricing in 2011 estimated at $\$ 1.4$ billion, this represents a tremendous source of income for rural Afghanis (UNODC [20]). If the Taliban remove this crop, without an efficient alternative crop that can compete with the economic return generated for these communities, it will further escalate the crisis in Afghanistan. While unlikely to end the largescale narcotics industry within Afghanistan, alternative cash crops such as saffron can present a crop alternative. Afghan grown saffron is valued between $\$ 1,200$ and 1,800 per kilogram, and during the coalition campaign was seen by some investors as a viable option to work towards lessening opium cultivation in the country (Razayee [25]).

\section{SECURITY RISKS TOWARDS ECONOMIC PARTNERSHIP}

The Taliban's current relationship with recognized Foreign Terrorist Organizations (FTOs) remains a primary concern in diplomatic relations. This exacerbates already fraught bureaucratic relationships in country. There are serving Taliban members with links to Al Qaeda, Al Qaeda in the Indian Subcontinent, The Haqqani Network, and additionally to some extent with the Pakistani Taliban and the Islamic Movement of Uzbekistan (IMU) (Congressional Research Service and Thomas [26]). Any idea the Taliban would sever ties with Al Qaeda negates their long and complex history - it is a relationship they have never broken. (Elias [27]). The ability of the Taliban to maintain consistent security for its citizens, as well as potential governmental partners and investors will be a chief economic risk facing the new regime. With so many historic ties to terrorist organizations operating and finding safe haven in Afghanistan, it will be interesting to see how the Taliban maintains control. Having the dual threat from IS-K, and the newly emerged National Resistance Front (NRF), the Taliban currently face major security and leadership challenges to effectively administering the country, its people, and resources.

While accurate numbers regarding the members of the foreign terrorist organizations are difficult to assess, a June 2021 publication from the UN Security Council estimated members of these organizations to be collectively in the thousands. Al Qaeda and Al Qaeda in the Indian Subcontinent are believed to collectively have upwards of 500 members in the border regions of Afghanistan/Pakistan. The Haqqani Network, seen as the liaison between Al Qaeda and the Taliban, are estimated to make up a major portion of identified Taliban fighters and specialists in the neighborhood of 3-10,000. The Pakistani Taliban have upwards of 6,000 fighters. The IMU have a strength estimated to total roughly 700 , including the families of the fighters. IS-K fighters are estimated between 1,500 and 2,200 in total. ETIM numbers are estimated as several hundred, potentially as many as 400 . Additionally, the UN report identifies fighters in northern Afghanistan from Khatiba Imam al-Bukhari (KIB) between 25 and 150 in total, and the Islamic Jihad Group with upwards of 100 fighters (Tirumurti [28]). All of these groups seek to challenge or exploit the current administrative apparatus of Afghanistan. 
The Taliban have claimed public victory over NRF fighters, a claim disputed by NRF leadership (Robertson and Regan [29]). The exact numbers of NRF membership is not known, and it may be as many as 10,000 , but the resistance fighters are reportedly not engaged in offensive operations as they prepare for winter (Coffey [30]). This suggests a possible surge in the spring, if survival through the coming winter can happen.

\section{RECOMMENDATIONS}

Given the state of crisis facing the people of Afghanistan, a path to stabilization would involve recognizing the Taliban officially and providing support to them as they transition into the role of official government. The Taliban - the new government of Afghanistan - will need outside support to return government functions for the people of Afghanistan. They will also need to be monitored to ensure any aid travelling into the country is utilized appropriately. With official recognition, Afghanistan could see the return of billions in development aid. This would provide a unique opportunity to leverage this aid with the Taliban and install a multinational monitoring group consisting of major and regional powers in Afghanistan to work with the government and individual aid agencies, ensuring its proper dispersal.

The emergence of extremists in Afghanistan would pose a huge threat to regional and even global stability. China is in a unique position to monitor any emerging extremist strongholds. China is motivated to do this by the threat extremists in Afghanistan have to their own stability in the Xinjiang region. It would be to the benefit of global anti-terrorism efforts to encourage China to step into a terrorism monitoring role in Afghanistan. China already has one unofficial military base in Tajikistan near the Afghanistan border and has just begun work on a second official base in Tajikistan (Standish [31]). This is a move on China's part to increase its physical security presence in Central Asia and provide a means for countering extremism in Afghanistan that could spill over into the Xinjiang region. It also provides a stepping point for China to spearhead an official, multinational anti-terrorism watch post within Afghanistan. Given that the Taliban has expressed in clear terms its wish to cooperate with Beijing on anti-terrorism, as well as their desire to receive the financial support that would come with China's Belt and Road initiative, there is real possibility for the Taliban agreeing to such an arrangement.

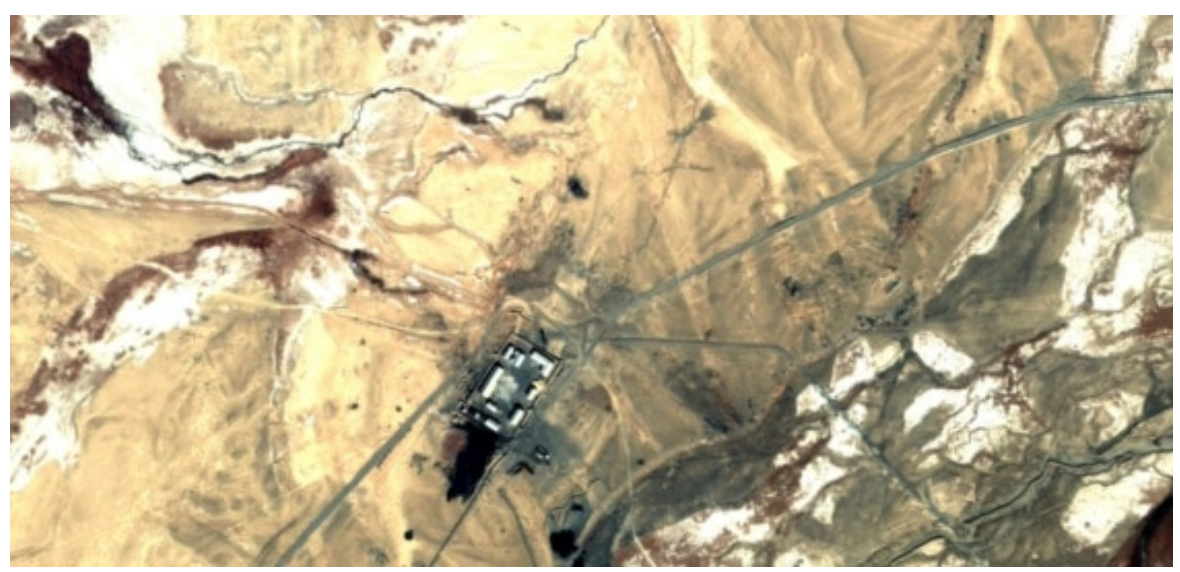

Figure 1: Military site near Shaymak before China's arrival [31]. 


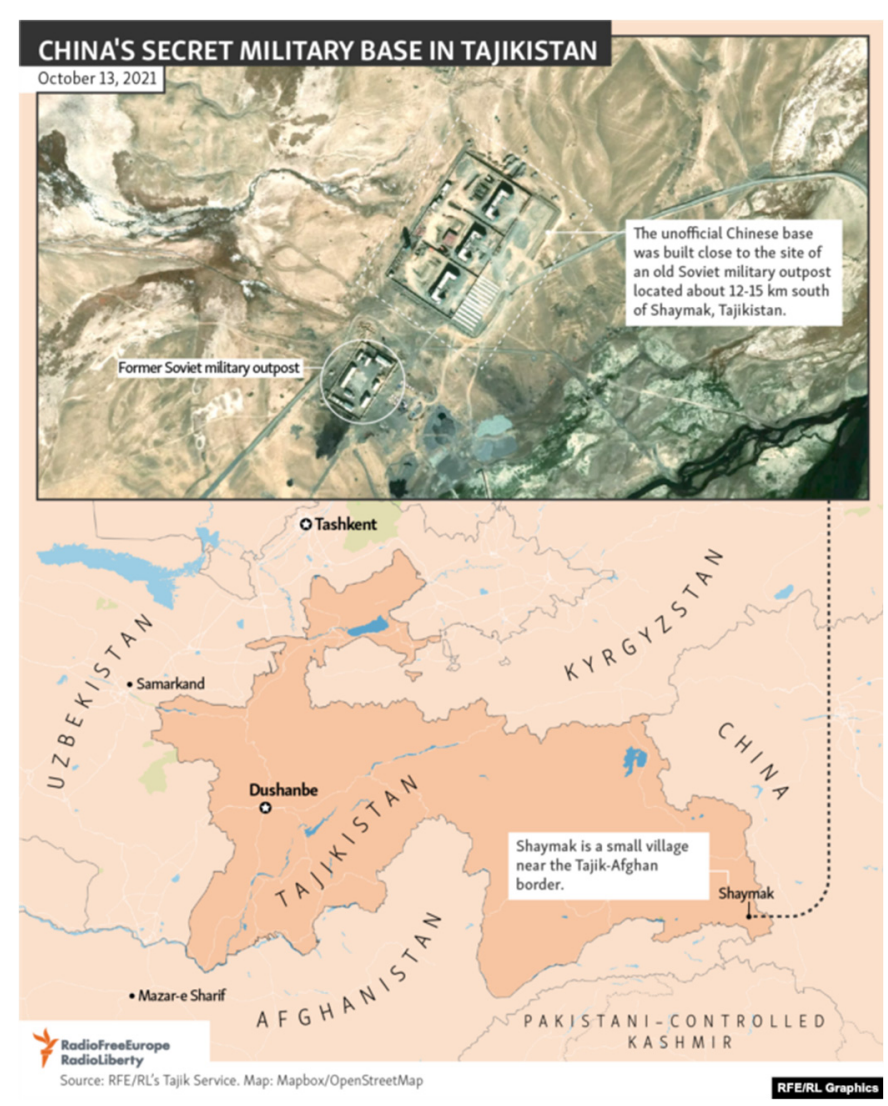

Figure 2: Base as of October 2021 after China's arrival [31].

\section{CONCLUSION}

Afghanistan is unlikely to stabilize without the reinstitution of international aid, the unfreezing of assets allocated towards governmental operations, or internal economic growth. All of these possibilities seem remote should the Taliban continue to go against the wishes of the international community. Long term economic sustainability is dependent upon their ability to establish cooperative relationships with their regional neighbors, principally with China, Pakistan, and Russia through incorporation into CPEC developments within China's Belt and Road Initiative, and their ability to effectively establish a reliable and safe infrastructure towards natural resource mining operations. The Taliban have expressed the desire to rid Afghanistan of opium cultivation, amongst other illegal narcotics, a decision which would further deteriorate the economic conditions of rural Afghanis. Additional concerns exist with the security of the region as IS-K initiates more violent attacks, and the NRF prepares for long term resistance to Taliban rule, along with the numerous terrorist organizations which continue to operate from Afghanistan. 


\section{REFERENCES}

[1] Rotberg, R., Failed states, collapsed states, weak states: Causes and indicators, 2003. https://www.brookings.edu/wp-content/uploads/2016/07/statefailureandstate weaknessinatimeofterror_chapter.pdf. Accessed on: 1 Nov. 2021.

[2] Iqbal, Z. \& Starr, H., Bad neighbors: Failed states and their consequences. Conflict Management and Peace Science, 25(4), pp. 315-331, 2008.

DOI: $10.1080 / 07388940802397400$.

[3] Ingber, R., Bureaucratic resistance and the national security state. 2 Oct. 2018. https://www.americanbar.org/content/dam/aba/events/administrative_law/2018 meetings/11/016-future-federal-civil-service.pdf. Accessed on: 4 Nov. 2021.

[4] CIA, Afghanistan: The world factbook. https://www.cia.gov/the-world-factbook/ countries/afghanistan/. Accessed on: 22 Oct. 2021.

[5] World Bank, The World Bank in Afghanistan. 2021. https://www.worldbank.org/en/ country/afghanistan/overview\#1. Accessed on: 26 Oct 2021.

[6] Rappeport, A., Afghanistan faces economic shock as sanctions replace foreign aid. The New York Times, 2021. https://www.nytimes.com/2021/08/21/business/afghanistaneconomy.html. Accessed on: 25 Oct. 2021.

[7] Boghani, P., "Brink of collapse": How frozen assets and halted foreign aid are impacting the Afghan people. Public Broadcasting Service, 2021.

https://www.pbs.org/wgbh/frontline/article/taliban-takeover-how-frozen-assetsforeign-aid-impacts-afghanistan/. Accessed on: 26 Oct. 2021.

[8] WFP, Afghanistan: WFP committed to averting humanitarian crisis as one in three people go hungry: World food programme. UN World Food Programme. https://www.wfp.org/stories/afghanistan-wfp-committed-averting-humanitariancrisis-one-three-people-go-hungry. Accessed on: 24 Oct. 2021.

[9] Putz, C., More than $\$ 1.2$ billion in humanitarian aid pledged to Afghanistan: The Diplomat for The Diplomat, 2021. https://thediplomat.com/2021/09/more-than-1-2billion-in-humanitarian-aid-pledged-to-afghanistan/. Accessed on 25 Oct. 2021.

[10] Pakistan Country Risk Report, Q1 2022. Fitch Solutions Risk Reports 2022, First: pp. $1-80$.

[11] Greenfield, C., Analysis: As west ponders aid for Afghanistan, China and Pakistan quick to provide relief. Reuters, 2021. https://www.reuters.com/world/middle-east/ west-ponders-aid-afghanistan-china-pakistan-quick-provide-relief-2021-09-12/.

Accessed on: 26 Oct. 2021.

[12] China-Pakistan Economic Corridor (CPEC), Progress. http://cpec.gov.pk/progressupdate. Accessed on: 26 Oct. 2021.

[13] The People's Republic of China, FM meets with acting deputy PM of Afghan Taliban's interim government, 2021. http://english.www.gov.cn/statecouncil/wangyi/202110/ 26/content_WS61774e4ac6d0df57f98e3ccc.html. Accessed on: 26 Oct. 2021.

[14] The People's Republic of China, FM urges lifting economic sanctions on Afghanistan at G20 meeting, 2021. http://english.www.gov.cn/statecouncil/wangyi/202109/23/ content_WS614c5c49c6d0df57f98e0ba2.html. Accessed on: 27 Oct. 2021.

[15] The People's Republic of China, China, Russia, Pakistan, Iran to strengthen coordination on Afghan issue, 2021. http://english.www.gov.cn/statecouncil/wangyi/ 202109/18/content_WS614534a4c6d0df57f98e0681.html. Accessed on: 27 Oct. 2021.

[16] Al Jazeera, China extends $\$ 31 \mathrm{M}$ in emergency aid to Afghanistan. Taliban News, Al Jazeera, 2021. https://www.aljazeera.com/news/2021/9/9/china-offers-31m-in-aid-3million-covid-shots-to-afghanistan. Accessed on: 27 Oct. 2021 
[17] World Bank, Population, total: Afghanistan. https://data.worldbank.org/indicator/SP. POP.TOTL?locations=AF. Accessed on: 27 Oct. 2021.

[18] Azami, D., Afghanistan: How do the Taliban make money. BBC News, 2021. https://www.bbc.com/news/world-46554097. Accessed on: 27 Oct. 2021.

[19] Daly, T. \& Singh, S., Factbox: What are Afghanistan's untapped minerals and resources? Thomson Reuters, 2021. https://www.reuters.com/world/asia-pacific/whatare-afghanistans-untapped-minerals-resources-2021-08-19/. Accessed on: 27 Oct. 2021.

[20] UNODC, Afghanistan Opium Survey 2020, 2021. https://www.unodc.org/documents/ crop-monitoring/Afghanistan/20210503_Executive_summary_Opium_Survey_2020 SMALL.pdf. Accessed on: 27 Oct. $202 \overline{1}$.

[21] Pikulicka-Wilczewska, A., Why is Afghanistan unable to extract its vast mineral wealth? Business and Economy, Al Jazeera, 2019. https://www.aljazeera.com/ features/2019/5/28/why-is-afghanistan-unable-to-extract-its-vast-mineral-wealth. Accessed on: 27 Oct. 2021.

[22] Kakar, J., Illegal mining, weak government help Taliban expand in Afghan north. Thomson Reuters, 2016. https://www.reuters.com/article/us-afghanistan-talibanmining/illegal-mining-weak-government-help-taliban-expand-in-afghan-northidUSKBN13114J. Accessed on: 27 Oct. 2021.

[23] George, S., Warrick, J. \& De Young, K., Pakistan using informal intelligence channels to prop up Taliban fight against Isis. The Washington Post.

https://www.washingtonpost.com/world/2021/10/23/afghanistan-isis-pakistanintelligence/. Accessed on: 27 Oct. 2021.

[24] Maizland, L., What is the Taliban? Council on Foreign Relations, 2021. https://www.cfr.org/backgrounder/taliban-afghanistan. Accessed on: 27 Oct. 2021.

[25] Razayee, J.A., Spice of life: Saffron harvest offers jobs, opportunity in Afghanistan. Thomson Reuters, 2016. https://www.reuters.com/article/us-afghanistan-saffronidUSKBN13I0CL. Accessed on: 27 Oct. 2021.

[26] Congressional Research Service \& Thomas, C., Terrorist Groups in Afghanistan, 13th ed., Library of Congress: Washington, DC, pp. 1-3, 2021.

[27] Elias, B., Why the Taliban won't quit Al Qaeda. Foreign Policy, 2021. https://foreignpolicy.com/2021/09/21/taliban-al-qaeda-afghanistan-ties-terrorism/. Accessed on: 27 Oct. 2021.

[28] Tirumurti, T.S., Twelfth report of the Analytical Support and Sanctions Monitoring Team submitted pursuant to resolution 2557 (2020) concerning the Taliban and other associated individuals and entities constituting a threat to the peace stability and security of Afghanistan, 2021.

[29] Robertson, N. \& Regan, H., Taliban claim to have "completely conquered" panjshir. Cable News Network, 2021. https://www.cnn.com/2021/09/06/asia/afghanistanmonday-intl-hnk/index.html. Accessed on: 27 Oct. 2021.

[30] Coffey, L., In Afghanistan, a resistance arises. The Heritage Foundation, 2021. https://www.heritage.org/terrorism/commentary/afghanistan-resistance-arises. Accessed on: 27 Oct. 2021.

[31] Standish, R., From a secret base in Tajikistan, China's war on terror adjusts to a new reality. 14 October, 2021. https://gandhara.rferl.org/a/tajikistan-china-war-on-terrorafghan/31509370.html. Accessed on: 4 Nov. 2021. 